\title{
IDentification of FAK substrate peptides via colorimetric screening of a one-bead one-peptide combinatorial library
}

\author{
Laurie A. Witucki, ${ }^{a *}$ Lauren Sanford Borowicz, ${ }^{\text {a,b }}$ Anthony M. Pedley, ${ }^{a, c}$ \\ Jaime Curtis-Fisk ${ }^{\mathrm{a}, \mathrm{d}}$ and Elizabeth Girnys Kuszpit ${ }^{\mathrm{a}}$
}

Focal adhesion kinase (FAK) is a protein tyrosine kinase that is associated with regulating cellular functions such as cell adhesion and migration and has emerged as an important target for cancer research. Short peptide substrates that are selectively and efficiently phosphorylated by FAK have not been previously identified and tested. Here we report the synthesis and screening of a one-bead one-peptide combinatorial library to identify novel substrates for FAK. Using a solid-phase colorimetric antibody tagging detection platform, the peptide beads phosphorylated by FAK were sequenced via Edman degradation and then validated through radioisotope kinetic studies with $\left[\gamma^{32} \mathrm{P}\right]$ ATP to derive Michaelis-Menton constants. The combination of results gathered from both colorimetric and radioisotope kinase assays led to the rational design of a second generation of FAK peptide substrates. Out of all the potential peptide substrates evaluated, the most active was GDYVEFKKK with a $K_{M}=92 \mu \mathrm{M}$ and a $V_{\max }=1920 \mathrm{nmol} / \mathrm{min} / \mathrm{mg}$. Peptide substrates discovered within this study may be useful diagnostic tools for future kinase investigations and may lead to novel therapeutic agents. Copyright $\odot 2015$ European Peptide Society and John Wiley \& Sons, Ltd.

Additional supporting information may be found in the online version of this article at the publisher's website.

Keywords: combinatorial peptide library; tyrosine kinase; FAK; substrate specificity; colorimetric

\section{Introduction}

The ability for a cell to sense and to adapt changes in its local microenvironment is mediated through the regulation of macromolecular protein complexes called focal adhesions [1,2]. Focal adhesions comprise a diverse array of enzymes and scaffolding proteins that activate signaling cascades leading to changes in cell behavior [3]. One of the first enzymes found at focal adhesions was the nonreceptor cytoplasmic protein tyrosine kinase focal adhesion kinase (FAK, p125 $5^{\mathrm{FAK}}$ ) [4]. Kinases are phosphotransferase enzymes and FAK specifically reacts at tyrosine residues.

Since its discovery, FAK activation has been shown through integrin-mediated cell adhesion and growth factor receptors $[5,6]$. Upon activation, FAK becomes autophosphorylated on residue Y397 and undergoes a conformational change to facilitate binding of additional kinases such as v-Src [7,8]. The identification of protein substrates and accessory proteins has given insight into how FAK plays a pivotal role in cell proliferation, survival, and migration. The phosphorylation of residue Y397 recruits Src to the active site where it phosphorylates additional residues such as Y925 that allows for Grb2 association and subsequent activation of the MAP kinase signaling pathway $[9,10]$. The phosphorylation of Y397 was also shown to promote the formation of protein-protein interactions with PI3K and p53 to regulate apoptosis [11-13]. Other notable substrates and accessory proteins for FAK include $130^{\text {Cas }}$, paxillin, talin, Grb7, and GTPase Regulator Associated with FAK (GRAF) [14-18].

The overexpression and constitutive activity of FAK have been associated with a number of cancers [19-24]. In ovarian and acute myeloid leukemia, FAK expression levels have been correlated with disease severity suggesting protein expression levels as a prognostic indicator $[25,26]$. The development of selective small molecule FAK inhibitors has given some insights into how FAK triggers dysregulation within cellular processes and promotes tumorigenesis and metastasis [27]. These small molecule inhibitors have been shown to prevent tumor progression implicating FAK as an attractive target for anticancer therapeutics [28-31]. Recently, dual inhibitors of FAK and insulin growth factor I receptor have shown promise in phase I clinical trials [32]. * Correspondence to: Laurie A. Witucki, Department of Chemistry, Grand Valley
State University, 354 Padnos Hall, Allendale, Michigan 49401, USA. E-mail:
wituckil@gvsu.edu

a Department of Chemistry, Grand Valley State University, Allendale, MI, 49401, USA

b University of Michigan, Ann Arbor, MI, 48109, USA

c Department of Chemistry, The Pennsylvania State University, University Park, PA, 16802, USA

d Dow Chemical Company, Midland, MI, 48674, USA

Abbreviations: ATP, adenosine triphosphate; BSA, bovine serum albumin; CPM, counts per min; DCM, dichloromethane; DIC, 1,3-diisopropylcarbodiimide; $D I E A, N, N$-diisopropylethylamine; DMF, dimethylformamide; Fmoc, 9-fluorenylmethoxycarbonyl; FAK, p125 focal adhesion kinase; HBTU, N,N,N,N'-Tetramethyl-O(1H-benzotriazol-1-yl)uronium hexafluorophosphate; HOBT, 1-hydroxybenzotriazole; $H P L C$, high performance liquid chromatography; PEG, polyethylene glycol; PyBOP, benzotriazole-1-yl-oxy-tris-pyrrolidinophosphonium hexafluorophosphate; TFA, trifluoroacetic acid; TIS, triisopropylsilane. 
Although small molecule inhibitors of FAK are being developed, there still exists a need for FAK-specific peptide-based probes for both enzyme activity and competition assays. Further, these substrates may guide the development of peptide biosensors and next generation FAK inhibitors as novel anticancer therapeutics. Herein, we aim to understand substrate specificity of FAK through the identification of novel peptide substrates. A one-bead onepeptide combinatorial library was synthesized and assayed using a colorimetric antibody tagging system to identify those peptide sequences that are phosphorylated by FAK. Validation of peptide substrates was performed by $\left[\gamma_{-}{ }^{32} \mathrm{P}\right]$ ATP isotopic labeling assays. Based on trends observed from the phosphoacceptor activity of the library peptides, additional substrates were designed, synthesized, and evaluated. This study marks the first time that short peptide substrates capable of being phosphorylated by FAK have been reported.

\section{Materials and Methods}

Unless otherwise mentioned, all reagents and supplies for solidphase peptide synthesis and associated assays were obtained from Sigma Aldrich (St. Louis, MO, USA), Novabiochem (Billerica, MA, USA), Fisher Scientific (Pittsburg, PA, USA), or VWR (Radnor, PA, USA). Specific resins used for peptide synthesis were (i) NovaSyn TG, 'TentaGel', resin beads, $90 \mu \mathrm{m}$ diameter, substitution of $0.27 \mathrm{mmol} / \mathrm{g}$ and (ii) Wang resin (polystyrene beads, $90 \mu \mathrm{m}$, 100-200 mesh, substitution of Fmoc-lys(boc)-OH varied from 0.27 to $0.66 \mathrm{mmol} / \mathrm{g}$, Novabiochem). Monoclonal mouse antiphosphotyrosine $\lg$ and alkaline phosphatase (AP)-goat antimouse IgG conjugate were obtained from Zymed Laboratories, Inc. (San Francisco, CA, USA). BM purple AP substrate was obtained from Roche Applied Science (Indianapolis, IN, USA); Whatman Phosphocellulose (p81) $2.5 \mathrm{~cm}$ paper discs, Fisher; $\left[\gamma^{-32} \mathrm{P}\right]$ ATP $(10 \mathrm{mCi} / \mathrm{ml}, 3000 \mathrm{Ci} / \mathrm{mmol}$, IsoBlue stabilized) was obtained from MP Biomedicals (Santa Ana, CA, USA) (formerly ICN Biomedicals); Scintisafe Plus 50\% liquid scintillation fluid, Fisher; Library Screening column: $1.5 \times 12 \mathrm{~cm}, 20 \mathrm{ml}$ bed volume polypropylene chromatography column with filter membrane, fitted with a stopcock at the bottom, Bio-Rad Laboratories (Hercules, CA, USA). Full-length active recombinant human FAK tyrosine kinase was purchased from Invitrogen (Life Technologies, Grand Island, NY, USA) as a GSTtagged protein expressed in sf9 insect cells and activated in vitro by His-tagged Src. The specific activity for the FAK used was typically $55 \mathrm{nmol} / \mathrm{min} / \mathrm{mg}$ (measured by phosphate transfer to poly [Glu, Tyr] 4:1 substrate). Protein stock concentration (measured by Bradford) was $0.39 \mathrm{mg} / \mathrm{ml}$. An AAPPTEC Apogee Peptide Synthesizer (Aapptec, Louisville, KY, USA) was used for individual peptide synthesis using HBTU/HOBT activation and Fmoc protected amino acids on a $0.25 \mathrm{~g}$ scale (amino acid loading varied from 0.27 to $0.66 \mathrm{mmol} / \mathrm{g}$ ). Analytical and preparative HPLC were performed with a Phenomenex column on either an Agilent 1100 Series HPLC with Chemstation data system (Agilent Technologies, Inc., Alpharetta, GA, USA) or on a Hitachi 7000 series HPLC (Hitachi High Technologies, Schaumburg, Illinois, USA). Automated peptide sequencing (of single beads) was performed using an Applied Biosystems model 476A, (Applied Biosystems Carlsbad, CA, USA) protein sequencer. Individual beads were sandwiched between two TFA-treated glass fiber filter discs (Applied Biosystems, Carlsbad, CA, USA) immediately after selection from the kinase on-bead assay and inserted directly into the sequencer. The peptide sequences for individually synthesized, pure peptide substrates were confirmed by Edman degradation sequencing on an AB4768 protein sequencer. Scintillation counting was performed on either a Packard 1900CA Tricarb liquid scintillation analyzer (PerkinElmer, Waltham, Massachusetts, USA) or on a Perkin Elmer 1450 LSC and processed with Microbeta Windows software (PerkinElmer, Waltham, Massachusetts, USA).

\section{Synthesis}

TentaGel controls—synthesis of tyrosine and Phosphotyrosine-TentaGel beads

Two TentaGel resin controls were synthesized to determine the best colorimetric labeling conditions with antibodies and BM purple AP substrate. Tyrosine-TentaGel and PhosphotyrosineTentaGel were synthesized manually using a fritted glass peptide synthesis reaction flask from Chemglass and employing Fmoc amino acids with HOBT/PyBOP, DIEA for coupling, and $20 \%$ piperdine/DMF for deprotection. Reaction completeness was monitored via ninhydrin tests. A fourfold excess of amino acid and coupling reagents was used relative to resin substitution. For the phosphotyrosine analog, Fmoc- $\operatorname{Tyr}\left(\mathrm{PO}(\mathrm{OH})_{2}\right)$ was used (Novabiochem). Side chain deprotection of the tyrosine-TentaGel beads was carried out with TFA/ $\mathrm{H}_{2} \mathrm{O} / \mathrm{TIS}(95: 2.5: 2.5)$ for $4 \mathrm{~h}$, the resin was filtered and washed once with TFA. The beads were washed five times with DCM, three times with 10\% DIEA/DMF, two times with DMF, once with 50:50 DMF/ $\mathrm{H}_{2} \mathrm{O}$, and four times with $\mathrm{H}_{2} \mathrm{O}$. Additional details are available in the Supporting Materials.

Library synthesis-preparation of the resin and synthesis of the pentaglycine linker

A total of $2.5 \mathrm{~g}\left(\sim 7.15 \times 10^{6}\right.$ beads, $\left.90 \mu \mathrm{m}\right)$ of NovaSyn TG (TentaGel) resin (Novabiochem, substitution: $0.27 \mathrm{mmol} / \mathrm{g}$ resin) was swelled in a $25-\mathrm{ml}$ glass fritted peptide reaction vessel with $4 \times 15 \mathrm{ml}$ of DMF for $30 \mathrm{~min}$ each. The pentaglycine $\left(\mathrm{Gly}_{5}\right)$ linker was synthesized using four equivalents Fmoc-Gly-OH. The first glycine was attached using DIC, HOBT, and DIEA (four equiv) over night, followed by double-coupling for $3 \mathrm{~h}$ until the reaction was complete by ninhydrin. The Fmoc group was removed via two treatments with $15 \mathrm{ml} 20 \%$ piperdine/DMF for $30 \mathrm{~min}$. The remaining four glycines were coupled to the beads using PyBOP/HOBT for coupling and a fivefold excess of each reagent (Fmoc-Gly, PyBOP, HOBT, and DIEA). Resin was washed six times with DMF after each coupling and deprotection step. Reaction completeness was assessed by the ninhydrin test.

Combinatorial peptide library synthesis_random positions using 'split-pool' method

Sixteen reaction tubes $(10 \mathrm{ml}$ size) were labeled with the amino acids to be used. The specific amino acid derivatives used in the combinatorial positions were Fmoc-Ala-OH, Fmoc-Arg-(pmc)-OH, Fmoc-Asn-(mtt)-OH, Fmoc-Asp-(tBu)-OH, Fmoc-Glu-(tBu)-OH, Fmoc$\mathrm{Gln}$-(mtt)-OH, Fmoc-Gly-OH, Fmoc-His-(mtt)-OH, Fmoc-lle-OH, Fmoc-Leu-OH, Fmoc-Lys-(Boc)-OH, Fmoc-Met-(OH)-OH, Fmoc-Phe-OH, Fmoc-Pro-OH, Fmoc-Trp-OH, and Fmoc-Val-OH.

The synthesized pentaglycine TentaGel beads were 'split' (pipetted as a slurry) into the 16 test tubes so as to evenly distribute the resin among the tubes by volume. PyBOP, HOBT, and DIEA were distributed evenly among the tubes, so that each tube contained four equivalents of each. One Fmoc amino acid (four equiv) was added to each tube and agitated until reaction completeness was indicated via ninhydrin test on bead aliquots removed from each 
reaction $(3 \mathrm{~h})$. The beads were then 'pooled', washed $4 \times$ each with DMF and DCM, and deprotected using 20\% piperdine/DMF for $45 \mathrm{~min}$. This split-pool procedure was followed for the remaining randomized positions with the following changes: Coupling and deprotection reaction times increased as the peptide chain grew - this was monitored by the ninhydrin test on all tubes, for example, the third library position $(X)$ took $4 \mathrm{~h}$, whereas the last coupling was allowed to react overnight. Additionally, the last Fmoc deprotection required a second treatment with $15 \mathrm{ml} \mathrm{50 \%}$ piperdine/DMF and a $2-\mathrm{h}$ reaction time.

\section{Coupling of tyrosine in the peptide library}

Four equivalents each of Fmoc-Tyr(tBu)-OH, PyBOP, HOBT, and DIEA were added to the peptide resin with $15 \mathrm{ml} \mathrm{DMF}$. After $2.5 \mathrm{~h}$, the reaction was complete; the beads were washed with DMF, followed by deprotection with $20 \%$ piperdine/DMF ( $1 \mathrm{~h})$, and subsequent washing with DMF.

\section{Library sidechain deprotection}

After coupling and Fmoc deprotection of the last randomized amino acid, the resin was washed five times with DMF, six times with DCM, four times with 1:1 DCM/methanol, and once with methanol and allowed to dry under vacuum and transferred to a dessicator containing $\mathrm{P}_{2} \mathrm{O}_{5}$. Side chain deprotection was carried out using $30 \mathrm{ml}$ of a cocktail containing $82.5 \%$ TFA, 5\% water, 5\% anisole, $5 \%$ phenol, and $2.5 \%$ TIS at room temperature for $4 \mathrm{~h}$. The beads were filtered, rinsed once with $10 \mathrm{ml}$ TFA, and washed six times with DCM and six times with methanol, and allowed to dry on vacuum. Three beads were removed for sequencing to determine the peptide purity of the sequence on an individual bead. Before storage of the library, the resin was washed three times with $10 \%$ DIEA/DMF, two times with DMF, once with $30 \%$ $\mathrm{H}_{2} \mathrm{O}$ /DMF, once with $60 \% \mathrm{H}_{2} \mathrm{O} / D M F$, and four times with water. Storage tubes (14) were washed two times with $0.01 \% \mathrm{HCl}(\mathrm{aq})$ prior to division of the resin into these tubes $(\sim 500,000-510,000$ beads per tube). Additional information can be found in the Supporting Materials.

\section{Bulk peptide synthesis of positive FAK substrates}

Defined peptide sequences were synthesized on $0.25 \mathrm{~g}$ of Wang polystyrene resin already coupled with Fmoc-Lys(Boc)-OH (Novabiochem, 100-200 mesh, substitution: $0.27-0.66 \mathrm{mmol} / \mathrm{g}$ resin) using an AAPPTEC Apogee automatic solid-phase peptide synthesizer under standard peptide synthesis conditions previously stated. Coupling times were $3 \mathrm{~h}$ per residue. Final side chain deprotection and resin cleavage was carried out with TFA/ $\mathrm{H}_{2} \mathrm{O} / \mathrm{TIS}$ $(95: 2.5: 2.5)$ for $4 \mathrm{~h}$. The resin was filtered and washed two times with a small amount of TFA. Water $(10 \% \mathrm{v} / \mathrm{v})$ was added to the combined filtrates and the solution agitated for $1 \mathrm{~h}$. The solvent was removed in vacuo, and the crude peptide precipitated by addition of cold ether. The precipitated peptide was washed five times with additional cold ether. Purity was assessed via reversephase HPLC on a Phenomenex $100 \AA, 150 \times 4.6 \mathrm{~mm}$ ID C18 analytical column with a gradient of $10-100 \%$ acetonitrile in water (containing $0.1 \%$ TFA) at absorbances of 214 and $280 \mathrm{~nm}$ over $20 \mathrm{~min}$ (flow rate $=1.0 \mathrm{ml} / \mathrm{min}$ ). Analytical HPLC was followed by preparative HPLC if necessary. Peptides used for the FAK assays were $>95 \%$ pure as determined by HPLC. Peptide sequences were confirmed by Edman degradation sequencing on an AB4768 sequencer.

\section{Phosphorylation Assays}

\section{On-bead colorimetric labeling with control beads}

A series of control reactions to determine the optimal on-bead assay and detection conditions were performed. The assays determined variables such as the optimal blocking buffer (concentration, $\mathrm{pH}$, etc), reaction and washing volume and $\mathrm{pH}$, and reaction time with BM purple AP substrate. Additional details are available in the Supporting Information. In general, control assays were performed on simple TentaGel beads that contained either tyrosine or phosphotyrosine. Optimal color differentiation was found with the following conditions: Samples of either $Y$ or pY on TentaGel beads were blocked using a $1 \%$ nonfat milk solution in PBS $\left(10 \mathrm{mM} \mathrm{NaH}_{2} \mathrm{PO}_{4}, 150 \mathrm{mM} \mathrm{NaCl}, \mathrm{pH} 7.4\right)$ at $37^{\circ} \mathrm{C}$ for a minimum of $1 \mathrm{~h}$ on an inverter mixer (blocking for additional time up to $6 \mathrm{~h}$ had no positive or negative effect). After blocking, mouse antiphosphotyrosine $\operatorname{lgG}(0.5 \mathrm{mg} / \mathrm{ml})$ was added directly to the blocking buffer and the beads agitated at room temperature for $1 \mathrm{~h}$. Following the primary antibody treatment, the beads were centrifuged at $4400 \mathrm{rpm}$ for $1 \mathrm{~min}$; the supernatant was decanted and the beads washed $3 \times 5 \mathrm{ml}$ with PBS-Tween washing buffer (10 mM NaH${ }_{2} \mathrm{PO}_{4}, 150 \mathrm{mM} \mathrm{NaCl}, \mathrm{pH} 7.4,0.1 \%$ Tween 20), followed by $3 \times 5 \mathrm{ml}$ PBS ( $10 \mathrm{mM} \mathrm{NaH}_{2} \mathrm{PO}_{4}, 150 \mathrm{mM} \mathrm{NaCl}, \mathrm{pH}$ 7.4). The beads were treated with blocking buffer as before (1\% nonfat milk solution in PBS for $1 \mathrm{~h}$ at $37^{\circ} \mathrm{C}$ ), followed by the addition of the secondary antibody AP-goat anti-mouse $\mathrm{lgG}(1 \mathrm{mg} / \mathrm{ml}$ stock). The beads were agitated for $1 \mathrm{~h}$ at room temperature and then washed as before. BM purple AP substrate was added (undiluted) and the beads mixed for $20 \mathrm{~min}$ followed by washing with $3 \times 5 \mathrm{ml}$ of water. The antibody tagging system used here is $\mathrm{pH}$ sensitive, buffers must be $\mathrm{pH} 7.2-7.4$, and the optimal reaction time with BM Purple AP substrate is $15-20 \mathrm{~min}$.

\section{In vitro on-bead FAK activity assay}

Two aliquots of the synthesized peptide library (XXYXXXGGGGGTentaGel) containing approximately 500,000 beads each $(\sim 1,000,000$ total) were placed into separate plastic screening columns-these can hold $15 \mathrm{ml}$ in addition to the beads. The beads were washed $6 \times 5 \mathrm{ml}$ with Tris buffer, $\mathrm{pH} 7.2$, and $6 \times 5 \mathrm{ml}$ with FAK kinase reaction buffer $(50 \mathrm{mM}$ Tris [pH 7.2], $10 \mathrm{mM} \mathrm{MgCl} 2,1 \mathrm{mM}$ $\mathrm{MnCl}_{2}$ ). To the beads, $250 \mu \mathrm{L}$ of a $10 \times$ stock of FAK kinase reaction buffer (500 mM Tris [pH 7.2], $100 \mathrm{mM} \mathrm{MgCl}, 100 \mathrm{mM} \mathrm{MnCl}$ ), $250 \mu \mathrm{L}$ of a $10 \times$ BSA solution $(10 \mathrm{mg} / \mathrm{ml}), 50 \mu \mathrm{L} 100 \mathrm{mM}$ ATP, $100 \mu \mathrm{L} 0.195 \mathrm{mg} / \mathrm{ml}$ active FAK enzyme solution (Life Technologies), and $1.85 \mathrm{ml}$ water were added (total volume $2.5 \mathrm{ml}$ ). The library was agitated for 30 min by gentle shaking on a vortex mixer followed by FAK denaturing by heating for 10 min in a $90^{\circ} \mathrm{C}$ water bath. The beads were washed for $10 \mathrm{~min}$ using $3 \times 5 \mathrm{ml}$ PBS-Tween washing buffer $\left(10 \mathrm{mM} \mathrm{NaH} \mathrm{PO}_{4}, \mathrm{pH} 7.4 ; 150 \mathrm{mM} \mathrm{NaCl} ; 0.1 \%\right.$ Tween 20) and $3 \times 5 \mathrm{ml} \mathrm{PBS}\left(10 \mathrm{mM} \mathrm{NaH}{ }_{2} \mathrm{PO}_{4}, \mathrm{pH} 7.4 ; 150 \mathrm{mM}\right.$ $\mathrm{NaCl}$ ). Beads were subjected to blocking buffer for $1 \mathrm{~h}$ using $2 \mathrm{ml}$ of a $1 \%(\mathrm{w} / \mathrm{v})$ nonfat milk solution in PBS $\left(10 \mathrm{mM} \mathrm{NaH} \mathrm{PO}_{4}\right.$, $150 \mathrm{mM} \mathrm{NaCl}, \mathrm{pH} 7.4$ ) at $37^{\circ} \mathrm{C}$. A $50 \mu \mathrm{L}$ aliquot of $0.5 \mathrm{mg} / \mathrm{ml}$ mouse anti-phosphotyrosine IgG (Zymed Laboratories, Inc.) was added to the blocking buffer, and the beads were agitated at room temperature for $1 \mathrm{~h}$. The beads were washed $3 \times 5 \mathrm{ml}$ PBS-Tween washing buffer followed by $3 \times 5 \mathrm{ml}$ PBS for $5 \mathrm{~min}$ each. A secondary antibody solution composed of $100 \mu \mathrm{L}$ of $0.5 \mathrm{mg} / \mathrm{ml} \mathrm{AP-goat} \mathrm{anti-}$ mouse IgG (Zymed Laboratories, Inc.) prepared in blocking buffer was added to the beads and mixed for $1 \mathrm{~h}$ at room temperature and then washed as before. Undiluted BM purple AP substrate 
( $4 \mathrm{ml}$, Roche Applied Science) was added to the beads, and the suspension was mixed for 20 min followed by three washes with $5 \mathrm{ml}$ of water. Those beads that presented a purple color (phosphorylated peptide sequence) were identified and sorted using a syringe needle and micro forceps under a standard dissecting microscope. Selected beads were individually sandwiched between two TFA-treated glass fiber filter discs (Applied Biosystems) and peptide sequenced by Edman degradation on an Applied Biosystems 476A protein sequencer.

Solution-based FAK kinetic assays of peptide substrates with $\left[\gamma_{-}^{32} \mathrm{P}\right]$ ATP

All in vitro kinase reactions $(30 \mu \mathrm{L})$ were performed at $30^{\circ} \mathrm{C}$ with $0.2 \mu \mathrm{g}$ FAK (Life Technologies) in kinase reaction buffer ( $50 \mathrm{mM}$ Tris [pH 7.2], $10 \mathrm{mM} \mathrm{MgCl}, 1 \mathrm{mM} \mathrm{MnCl}_{2}$, and $1 \mathrm{mg} / \mathrm{ml} \mathrm{BSA).} \mathrm{To}$ determine Michaelis-Menton kinetics on the various peptide substrates containing a C-terminal polylysine tail, a saturating concentration of ATP $(200 \mu \mathrm{M})$ supplemented with $1000 \mathrm{cpm} / \mathrm{pmol}$ $\left[\gamma^{32} \mathrm{P}\right]$ ATP (MP Biomedicals) was used. Initial peptide activity screening conditions used $300 \mu \mathrm{M}$ peptide and $100 \mu \mathrm{M}$ ATP supplemented with $1000 \mathrm{cpm} / \mathrm{pmol}\left[\gamma_{-}{ }^{32} \mathrm{P}\right]$ ATP. For peptide kinetic studies, varying concentrations of peptide were used, ranging from 0.125 to $8 \times$ the $K_{M}$ value. Reactions were initiated by the addition of kinase and quenched after $15 \mathrm{~min}$ by spotting $25 \mu \mathrm{L}$ of the $30 \mu \mathrm{L}$ total reaction volume onto a piece of Whatman $2.5 \mathrm{~cm}$ phosphocellulose (p81) paper. Filter papers were washed for $30 \mathrm{~min}$ with $10 \%$ acetic acid followed by three 10-min washes with $0.5 \%$ phosphoric acid and a final 5-min wash with acetone. The washed and dried filter discs were placed into scintillation vials with $5 \mathrm{ml}$ scintillation fluid, and ${ }^{32} \mathrm{P}$ incorporation was measured on a Packard 1900CA Tricarb liquid scintillation analyzer or a Perkin Elmer 1450 LSC analyzer. Kinase reactions were performed in triplicates and background subtracted (standard error $<15 \%$ ). $K_{M}$ and $V_{\max }$ values were determined by double-reciprocal plots, constructed from initial rate measurements fitted to the Michaelis-Menton equation.

\section{Results}

Previous studies have established the utility of one-bead onepeptide combinatorial libraries in the identification of bioactive peptides [33]. These include novel peptide-based substrates for kinases such as those determined for the protein tyrosine kinase c-Src using radioisotopic labeling for detection of the phosphorylated beads $[34,35]$. Active peptide substrates were also determined via a combinatorial library assay followed by colorimetric labeling using antibody tagging for the tyrosine kinases C-Src and ZAP-70 [36]. Using a similar approach, we likewise merged the use of a large combinatorial solid-phase one-bead one-peptide library with a colorimetric antibody tagging system (to eliminate the use of radioactivity) and applied this approach to a previously uncharacterized protein tyrosine kinase, FAK.

\section{Combinatorial Library Design and Synthesis}

The combinatorial peptide library was synthesized by the 'splitpool' method as previously described $[37,35,38]$. The sequence of this library was XXYXXX-GGGGG-TentaGel, where $Y$ represents the tyrosine residue and $X$ represents any random amino acid with the exception of tyrosine, serine, threonine, and cysteine (Figure 1). Cysteine is typically excluded from combinatorial libraries to

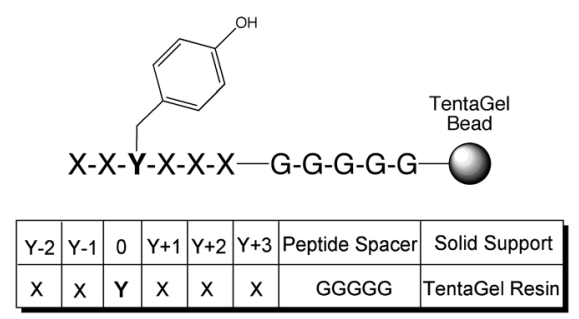

Figure 1. One-bead one-peptide combinatorial library design. Hexapeptides were synthesized on TentaGel resin with a poly-glycine spacer. In order to refer to a specific randomized position $(X)$, the library is numbered relative to the phosphorylatable tyrosine $(Y)$ residue.

prevent disulfide bond formation in the library. The other excluded amino acids ( $\mathrm{S}, \mathrm{T}$, and $\mathrm{Y}$ ) all contain a hydroxyl group; these were omitted from the library so that only one possible site for phosphorylation by FAK would be present, that being the 'set' tyrosine at position 0 . Poly(ethylene glycol)-grafted polystyrene resin, TentaGel-S- $\mathrm{NH}_{2}$, was used as the solid-phase support, because the PEG linker is beneficial to the aqueous environment during the kinase assay and antibody screening system. Although the TentaGel resin contains a flexible PEG linker, many researchers use short 'peptide spacers' before the combinatorial library positions-options for these spacers include multiple $\beta$-alanine residues or glycine residues [39-42]. Here, the library was tethered to TentaGel by a spacer peptide of five glycine residues. This C-terminal poly-glycine spacer ensures that the solid support does not interfere with the enzymatic reaction and downstream colorimetric detection.

The number of unique sequences possible is slightly over 1 million $\left(16^{5}=1,048,576\right)$. The synthesized library was designed with two randomized positions ( $\mathrm{Y}-1$ and $\mathrm{Y}-2) \mathrm{N}$-terminal and three randomized positions $(Y+1, Y+2$, and $Y+3) C$-terminal to the tyrosine residue. Many studies have shown that protein tyrosine kinases display a strong preference for amino acids at the $Y+3$ position and very little preference at the $\mathrm{Y}-3$ position [43]. Ultimately, the library was kept at a hexapeptide length (XXYXXX) in order to find short, minimal length peptides that could act as effective substrates for FAK.

\section{Library Verification: Sequencing of Control Beads}

Peptide bead sequencing was performed on three of the beads from the synthesized library before reaction with FAK. There is approximately $100 \mathrm{pmol}$ (or $10^{13}$ copies) of the same peptide on each bead $(90 \mu \mathrm{M}$ size TentaGel) $[37,44]$. Amounts as low as 1-5 pmol of amino acid are commonly detected with Edman degradation sequencing. Our results confirmed that a single bead from the synthesized library contains enough amino acid at each position for sequencing and that each bead contains one unique peptide. The unique peptide sequences obtained from these control beads were (i) QFYNPG-GGGGG, (ii) IFYIHK-GGGGG, and (iii) ARYELW-GGGGG. The sequences also show the diversity of amino acids possible at each position in the library, because a total of 13 unique amino acids were determined at the five randomized positions in these three peptides.

\section{Library Screening to Identify Peptide Substrates for FAK}

Once synthesized, the library beads were reacted with FAK and ATP. A variety of different techniques have been previously employed to screen for kinase activity using one-bead one-peptide 
combinatorial libraries and are summarized in the review by Lee et al. [45]. In our study, the FAK-phosphorylated peptide beads were detected using a colorimetric antibody tagging system developed by Martin and Peterson [46]. This colorimetric method mimics an on-bead ELISA assay and was used in their study on two peptides that were known substrates for the tyrosine kinase Abl. In our study, the labeling conditions were optimized for FAK. Briefly, for this detection system, a primary anti-phosphotyrosine lgG will recognize whether the peptide substrate is phosphorylated by FAK. A secondary antibody conjugated with AP will recognize the primary antibody and react with the BM purple AP substrate. If the peptide substrate was phosphorylated, then the bead will appear purple under a standard dissecting microscope (Figure 2).

Control reactions were performed to determine the ideal conditions for the antibody tagging system using different concentration of antibody, formulation and $\mathrm{pH}$ of the blocking buffer, reaction $\mathrm{pH}$, reaction and labeling times, and number of washing steps. No false positive beads (nonspecific labeling) were obtained during these control reactions, verifying that the bead would only turn purple when the peptide contained phosphotyrosine. Before the library was reacted, labeling experiments were performed on two sets of control beads: (i) tyrosine-TentaGel beads and (ii) Phosphotyrosine-TentaGel beads,

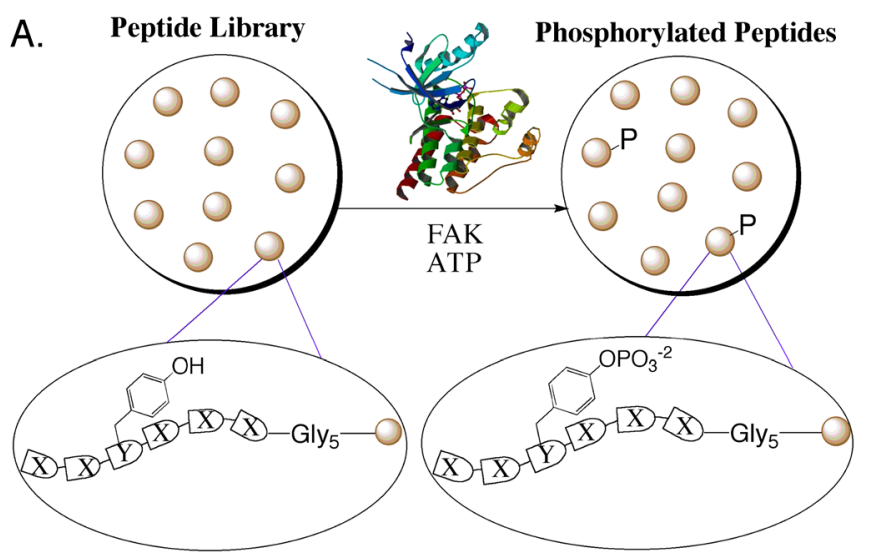

\section{B. Colorimetrically Labeled
Phosphorylated Peptides}

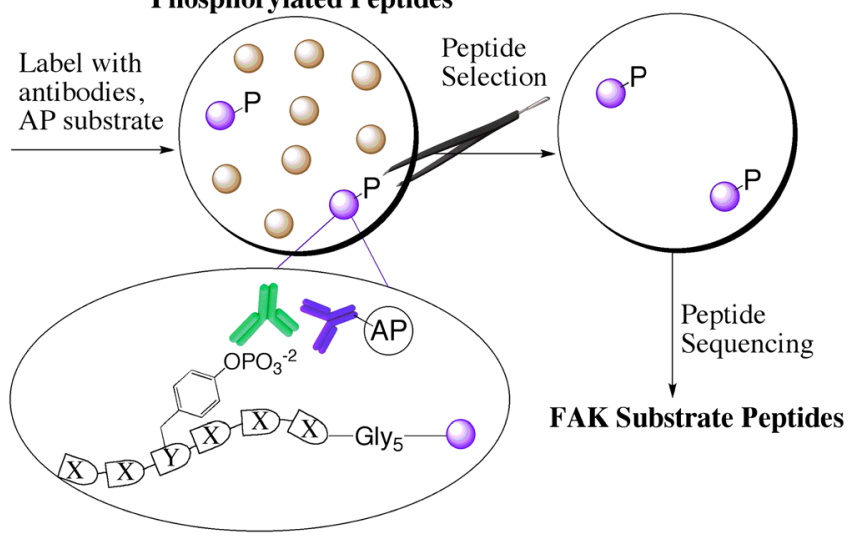

Figure 2. This scheme shows the approach used to identify peptide substrates for the protein tyrosine kinase, focal adhesion kinase (FAK). (A) The combinatorial peptide library was reacted with FAK and ATP. (B) The library beads were subjected to a colorimetric antibody tagging system and BM Purple alkaline phosphatase (AP) substrate whereby phosphorylated beads turned purple and were selected under a microscope. Selected beads were sent for Edman degradation peptide sequencing to determine the identity of the FAK substrates. in order to optimize the conditions such that the most dramatic color difference between phosphotyrosine and tyrosine was produced (Figure 3).

In order to determine the optimal short peptide sequences that would serve as efficient substrates for FAK, we desired to limit the number of positive or 'hit' peptides from the library screen to approximately 10-20 sequences. The efficiency with which FAK phosphorylates the library peptides was determined by three control time-dependent reactions of approximately 250,000 beads each. The library beads were reacted with FAK for 1,2 , and $24 \mathrm{~h}$ and resulted in 29,62, and 85 purple beads, respectively.

To verify that the stained beads could be sequenced directly without additional washing steps, one purple bead was selected (from the $1 \mathrm{~h}$ reaction) and sequenced. A clean peptide sequence resulted (IAYDEL-GGGGG) indicating no additional washing or protein denaturation steps were needed to remove protein, antibodies or BM purple from the resin. Based on these experiments, the length of time to react the peptide library with FAK was set at $30 \mathrm{~min}$. A larger aliquot of the library $(\sim 1,000,000$ beads) was chosen for this final FAK substrate library screen.

A<smiles>CCCc1ccc(O)cc1</smiles>

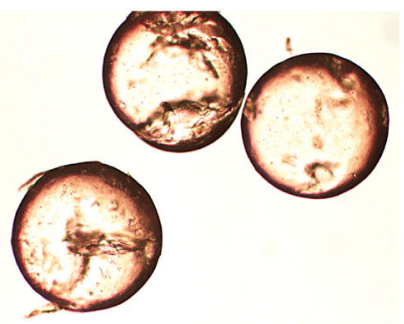

B

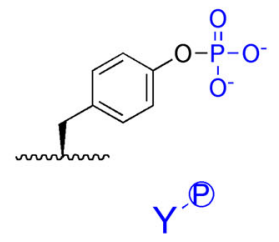

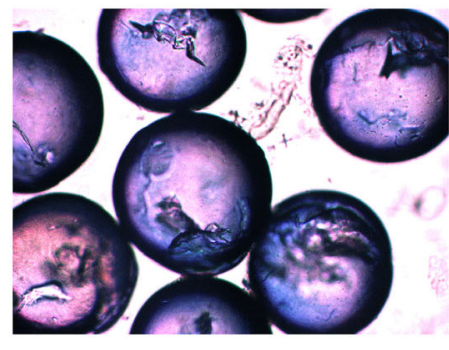

C
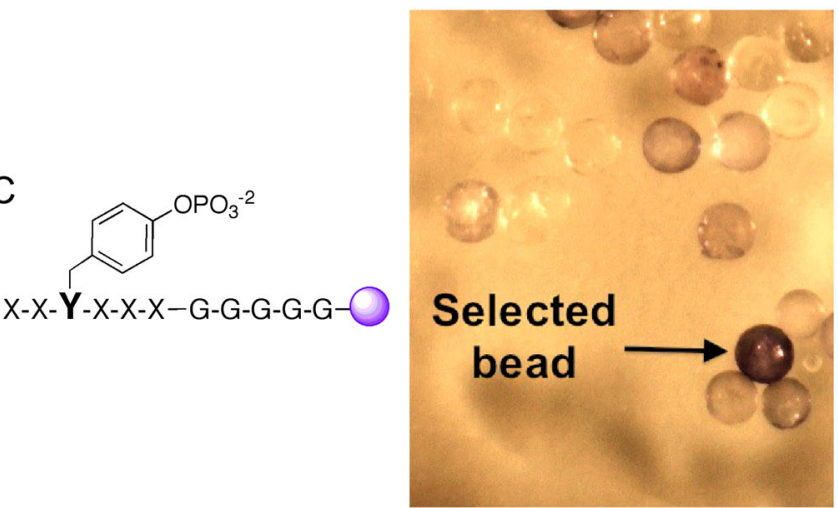

Figure 3. TentaGel beads were subjected to phosphotyrosine labeling as described in the Materials and Methods section. (A) Tyrosine-TentaGel beads treated with mouse anti-phosphotyrosine antibody, AP-goat antimouse lgG, and BM Purple AP substrate, these beads showed no signs of purple staining. (B) Phosphotyrosine-TentaGel beads treated as above, these showed dark purple staining. (C) Library assay with focal adhesion kinase followed by colorimetric labeling as described. Only the darkest purple beads were counted as focal adhesion kinase substrates, these were selected and sequenced. 


\begin{tabular}{|c|c|c|c|c|c|c|}
\hline \multirow{2}{*}{$\begin{array}{l}\text { Peptide Library } \\
\text { FAK Substrates }\end{array}$} & \multicolumn{6}{|c|}{ Position } \\
\hline & $\mathrm{Y}-2$ & Y-1 & Y & $\mathrm{Y}+1$ & $Y+2$ & $Y+3$ \\
\hline LIB1 & $\mathrm{N}$ & V & $\mathbf{Y}$ & $\mathrm{E}$ & I & M \\
\hline LIB2 & G & I & $\mathbf{Y}$ & $\mathrm{F}$ & $\mathrm{H}$ & $E$ \\
\hline LIB3 & G & E & $\mathbf{Y}$ & V & V & D \\
\hline LIB4 & $M$ & K & $\mathbf{Y}$ & M & $P$ & Q \\
\hline LIB5 & W & $\mathrm{N}$ & $\mathbf{Y}$ & $\mathrm{L}$ & I & $\mathrm{H}$ \\
\hline LIB6 & 1 & $D$ & $\mathbf{Y}$ & V & E & W \\
\hline LIB7 & 1 & $\mathrm{~N}$ & $\mathbf{Y}$ & $E$ & $\mathrm{~L}$ & $P$ \\
\hline LIB8 & G & 1 & $\mathbf{Y}$ & A & $\mathrm{R}$ & K \\
\hline LIB9 & $\mathrm{E}$ & $\mathrm{L}$ & $\mathbf{Y}$ & Q & $\mathrm{N}$ & $P$ \\
\hline LIB10 & L & $\mathrm{R}$ & $\mathbf{Y}$ & $\mathrm{F}$ & W & $E$ \\
\hline LIB11 & G & K & $\mathbf{Y}$ & $\mathrm{R}$ & $M$ & V \\
\hline LIB12 & $X^{*}$ & $D$ & $\mathbf{Y}$ & E & $\mathrm{L}$ & $\mathrm{F}$ \\
\hline
\end{tabular}

The library beads were then subjected to FAK for $30 \mathrm{~min}$, and 12 highly positive beads (dark purple) were identified, selected, and sent for sequencing by Edman degradation sequencing (Figure 3 ).

Table 1 summarizes the peptide sequences originating from the 12 positive beads in the FAK library assay. All but one peptide bead gave a complete and clean sequence. The amino acid residue at the Y-2 position of LIB12 was not determined because of instrument malfunction.

Analysis of the peptide substrate sequences from the library screen showed that FAK selects substrates containing negatively charged amino acids (glutamate and aspartate), these occurred 11 times overall in the sequences as opposed to positively charged amino acids ( $K$ and $R$ ), which occurred only five times. This finding is in agreement with previous studies that showed many protein tyrosine kinases (Src, Lyn, Syk, and Abl) have a preference for acidic residues flanking the phosphorylation site [47-50]. Additionally, our results indicated that N-terminal positions $\mathrm{Y}-1$ and $\mathrm{Y}-2$ had a preference for bulky hydrophobic residues, such as isoleucine, leucine, and valine, which occurred seven times, or for glycine (four occurrences). FAK selected for aromatic residues (phenylalanine and tryptophan) more frequently at the C-terminus rather than the $\mathrm{N}$-terminus (five occurrences vs one). From the peptides with complete sequences (LIB1-LIB11), the two most common amino acids at the Y-2 position were glycine and isoleucine with four and two occurrences, respectively. The observed preference for isoleucine or glycine at the Y-2 site was used to justify the design of two new peptide sequences (LIB12a and LIB12b) to compensate for the loss of data at this position during Edman sequencing on one of the library 'hit' beads, $X^{*}$ DYELF.

\section{Hit Validation by Kinetic $\left[\gamma^{32} \mathrm{P}\right]$ ATP Assays}

The resulting peptide sequences (LIB1-LIB12b) identified by the one-bead one-peptide combinatorial library were synthesized in bulk on Wang resin to generate enough material for solution-based validation studies. These studies utilized $\left[\gamma^{32} \mathrm{P}\right]$ ATP in order to validate the library hits and compare Michaelis-Menton kinetics.
Table 2. Thirteen peptides were synthesized individually based on the peptide sequences determined following the library reaction with FAK

\begin{tabular}{|c|c|c|c|c|c|c|c|}
\hline \multirow{2}{*}{$\begin{array}{l}\text { Synthesized } \\
\text { peptides }\end{array}$} & \multicolumn{7}{|c|}{ Position } \\
\hline & $\mathrm{Y}-2$ & $\mathrm{Y}-1$ & Y & $Y+1$ & $Y+2$ & $Y+3$ & Polylysine tail \\
\hline LIB1 & $\mathrm{N}$ & V & $\mathbf{Y}$ & $\mathrm{E}$ & 1 & $M$ & KKK \\
\hline LIB2 & G & 1 & $\mathbf{Y}$ & $\mathrm{F}$ & $\mathrm{H}$ & $\mathrm{E}$ & KKK \\
\hline LIB3 & G & $\mathrm{E}$ & $\mathbf{Y}$ & V & V & $\mathrm{D}$ & KKK \\
\hline LIB4 & M & $\mathrm{K}$ & $\mathbf{Y}$ & M & $P$ & $\mathrm{Q}$ & KKK \\
\hline LIB5 & W & $\mathrm{N}$ & $\mathbf{Y}$ & $\mathrm{L}$ & 1 & $\mathrm{H}$ & KKK \\
\hline LIB6 & 1 & D & $\mathbf{Y}$ & V & $E$ & W & KKK \\
\hline LIB7 & I & $\mathrm{N}$ & $\mathbf{Y}$ & $\mathrm{E}$ & L & $\mathrm{P}$ & KKK \\
\hline LIB8 & G & 1 & $\mathbf{Y}$ & A & $\mathrm{R}$ & K & KKK \\
\hline LIB9 & $E$ & L & $\mathbf{Y}$ & Q & $\mathrm{N}$ & $P$ & KKK \\
\hline LIB10 & L & $\mathrm{R}$ & $\mathbf{Y}$ & $\mathrm{F}$ & W & E & KKK \\
\hline LIB11 & G & $\mathrm{K}$ & $\mathbf{Y}$ & $\mathrm{R}$ & M & V & KKK \\
\hline LIB12a & G & D & $\mathbf{Y}$ & $\mathrm{E}$ & $\mathrm{L}$ & $\mathrm{F}$ & KKK \\
\hline LIB12b & I & D & $\mathbf{Y}$ & E & L & $\mathrm{F}$ & KKK \\
\hline
\end{tabular}

These peptides were synthesized on Wang resin and cleaved from the solid support. Each incorporated the use of a polylysine tail on the C-terminus in order to employ a phosphocellulose paperbinding assay. The phosphorylatable tyrosine residue, $\mathrm{Y}$, is shown in bold.

To facilitate the radioactive kinetics assay, each peptide sequence was synthesized with a C-terminal poly-lysine tail to promote peptide binding to phosphocellulose paper via electrostatic interactions. For in vitro kinase assays, the use of positively charged amino acids (arginine and lysine) at the C-terminus of a kinase substrate is well known [51,52]. Overall, 13 novel peptides were synthesized; these sequences are summarized in Table 2.

In the kinetic assays, all 13 peptides tested were validated as substrates for FAK by measuring the amount of ${ }^{32} \mathrm{P}$ incorporated onto the FAK peptide substrate using liquid scintillation counting. An activity profile of all peptides tested is shown in Figure 4. The highest scintillation counts (average of triplicate runs, peptide concentration $300 \mu \mathrm{M}$ ) were found in peptides LIB1, LIB6, LIB12a, and LIB12b. In

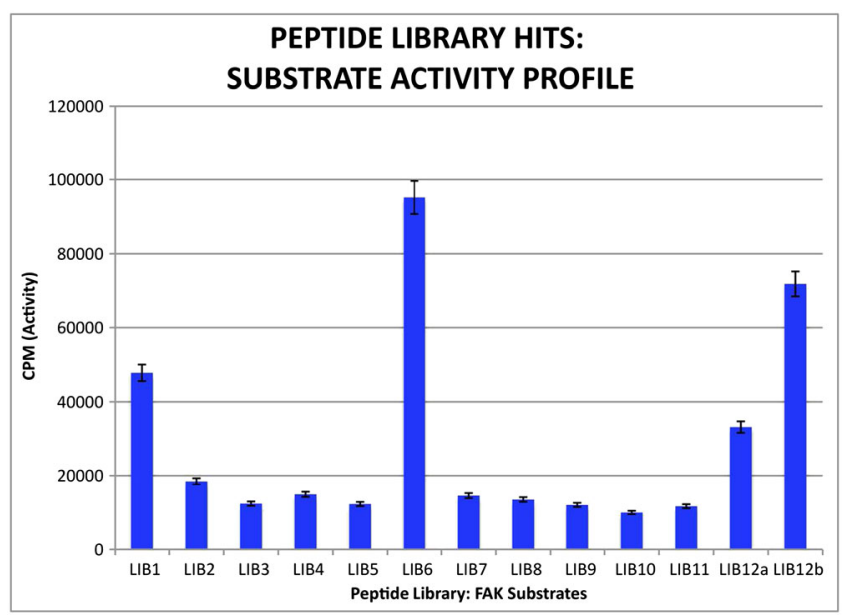

Figure 4. Library peptide hits assayed with FAK tyrosine kinase and $\gamma-\left[{ }^{32} \mathrm{P}\right]$ ATP in a solution-phase phosphocellulose paper binding assay and counted on a liquid scintillation counter. Phosphorylation activity (incorporation of ${ }^{32} \mathrm{P}$ ) is corrected for background and shown as cpm. Data are the average of triplicate trials. Peptide concentration for this assay was $300 \mu \mathrm{M}$. All peptides assayed displayed activity as FAK substrates. 
order of activity, these sequences are as follows: LIB6 (IDYVEWKKK), LIB12b (IDYELFKKK), LIB12a (GDYELFKKK), and LIB1 (NVYEIMKKK).

From the radioisotopic data, the general activity trends for FAK substrates were classified into three common areas as follows: (i) negatively charged amino acids were preferred flanking the tyrosine residue $(\mathrm{Y}-1$ and/or $\mathrm{Y}+1)$, (ii) there was an increase in hydrophobic and bulky groups (isoleucine, leucine, and phenylalanine) at positions $Y+2$, and $Y+3$, and lastly, (iii) an additional aromatic amino acid residue (phenylalanine and tryptophan) was present in three of the active substrates.

Michaelis-Menton kinetic analysis was performed on the four most active peptide substrates discussed earlier. Individual data points were averaged and plotted in a double-reciprocal plot to extract $K_{M}$ and $V_{\max }$ values and shown in Table 3 . The most active peptide tested was LIB6 with a calculated efficiency $\left(V_{\max } / K_{M}\right)$ twofold greater than LIB12b and approximately 7.5-fold greater than the other most active library peptides tested. The $K_{M}$ of IDYVEWKKK (LIB6) was in the mid micromolar range $(318 \mu \mathrm{M})$, and although there are peptide substrates for some well-studied kinases (i.e., Src and Abl) that have lower reported $K_{M}$ values, a $K_{M} \sim 300 \mu \mathrm{M}$ for FAK may prove to be useful. Although this lead peptide does not exhibit as tight of binding as desired, these data allow for the design of a second generation of peptide substrates for FAK.

\section{Development and Screening of Second Generation Peptide Substrates for FAK}

A total of five second generation potential FAK substrates were designed (prefix DES-) and synthesized based on the previous kinetic data. Each of these peptides followed the library sequence (XXYXXX) but incorporated negatively charged (aspartate and glutamate), hydrophobic (isoleucine, leucine, and valine), and aromatic (phenylalanine and tryptophan) residues at various positions derived from the most active substrates selected during the library screen and subsequent kinetic analysis (Table 4).

The new designed peptides were assayed by the previously mentioned kinetics assay with FAK and $\gamma-\left[{ }^{32} \mathrm{P}\right]$ ATP, and the activity was compared between all peptides tested (Figure 5). Based on the findings, the best FAK substrate was DES4 $\left(K_{M}=92 \mu \mathrm{M}\right)$ with the sequence GDYVEFKKK. In fact, the activity of both DES3 (GDYVEWKKK, $K_{M}=223 \mu \mathrm{M}$ ) and DES4 surpassed the most active library hit peptide, LIB6 $\left(K_{M}=318 \mu \mathrm{M}\right)$. These kinetic data indicate that the overall efficiency of DES4 is two times greater than that of LIB6 (Table 5). Additionally, all of the designed peptides had activity higher than nine of the original library hit peptides. DES3 had comparable efficiency with LIB6. The next most active substrates were DES1 and LIB12b.

Table 3. Kinetic analysis of the four most active FAK substrate peptides determined from the initial combinatorial library assay

\begin{tabular}{|lcccc|} 
Peptide & Sequence & $K_{M}(\mu \mathrm{M})$ & $\begin{array}{c}V_{\max } \\
(\mathrm{nmol} / \mathrm{min} / \mathrm{mg})\end{array}$ & $\begin{array}{c}\text { Efficiency } \\
\left(V_{\max } / K_{M}\right)\end{array}$ \\
\hline LIB1 & NVYEIM-KKK & 609 & 861 & 1.41 \\
LIB6 & IDYVW-KKK & 318 & 3341 & 10.5 \\
LIB12a & GDYELF-KKK & 813 & 1189 & 1.46 \\
LIB12b & IDYELF-KKK & 503 & 2532 & 5.0 \\
\hline
\end{tabular}

Data represent averages of triplicate runs. Standard error for all reported kinetic constants is $\leq 15 \%$.
Table 4. Peptide sequences designed as FAK substrates based on activity determined from the active peptides from the library screen

\begin{tabular}{|lc|}
\hline Peptide designation & Peptide sequence \\
\hline DES1 & IDYVEF-KKK \\
DES2 & IDYELW-KKK \\
DES3 & GDYVEW-KKK \\
DES4 & GDYVEF-KKK \\
DES5 & EDYELF-KKK \\
\hline \multicolumn{2}{l}{ These five peptides were synthesized as described in the Materials and } \\
Methods section and treated with FAK to evaluate their ability to act \\
as FAK phosphoacceptors. \\
\hline
\end{tabular}

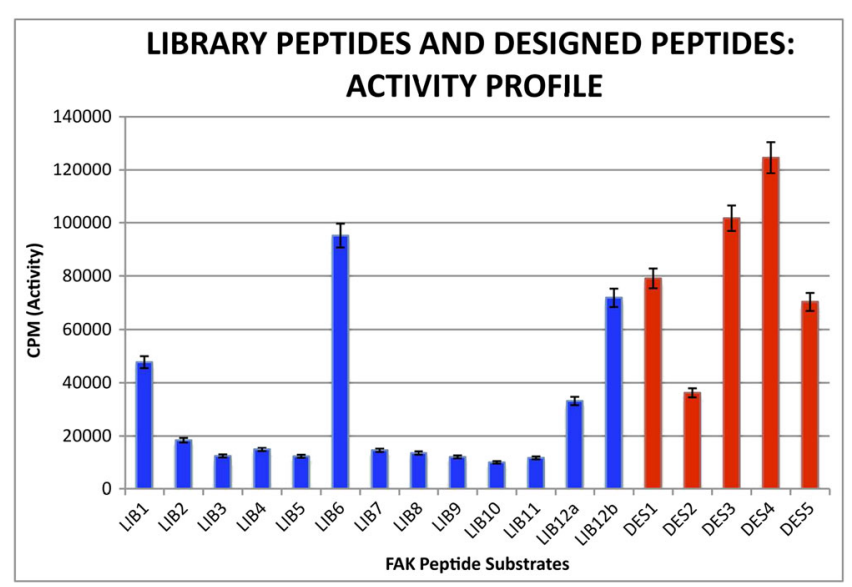

Figure 5. Focal adhesion kinase activity comparison profile of the original library peptide hits, shown in blue bars, with the newly designed peptides (DES1-DES5), shown in red bars. All peptides were tested in triplicate at the same concentration $(300 \mu \mathrm{M})$ as described in the Materials and Methods section.

Table 5. The kinetic values for the DES peptides designed as FAK substrates

\begin{tabular}{|llccc|} 
Peptide & Sequence & $\begin{array}{c}K_{M} \\
(\mu \mathrm{M})\end{array}$ & $\begin{array}{c}V_{\max } \\
(\mathrm{nmol} / \mathrm{min} / \mathrm{mg})\end{array}$ & $\begin{array}{c}\text { Efficiency } \\
\left(V_{\max } / K_{M}\right)\end{array}$ \\
\hline DES1 & IDYVEF-KKK & 319 & 2051 & 6.4 \\
DES2 & IDYELW-KKK & 987 & 911 & 0.92 \\
DES3 & GDYVEW-KKK & 223 & 2430 & 10.9 \\
DES4 & GDYVEF-KKK & 92 & 1920 & 20.9 \\
DES5 & EDYELF-KKK & 404 & 785 & 1.94 \\
\hline
\end{tabular}

Data represent the means of three separate determinations. Standard error for all reported kinetic constants is $\leq 15 \%$.

\section{Discussion}

The identification of high affinity peptide-based probes has important utility in a variety of enzyme-based activity and competition assays. One of the first Src-specific peptide substrates found, 'RR-Src' (RRLIEDAEYAARRG, $K_{M}=2.8 \mathrm{mM}$ ), was designed based upon Src's autophosphorylation site and was routinely used for activity assays [53]. The usefulness of an active peptide substrate for a given protein kinase can lead to high throughput screening methods for kinase inhibitors as shown by the utility of the Src substrate Ac-IYGEFKKKC-NH $\mathrm{N}_{2}$ that was conjugated to a peptide chip and 
analyzed for kinase and inhibitor activity by phosphoimaging [54]. For the protein kinase Src, short peptides were identified via combinatorial peptide library methods, providing sequences YIYGSFK and GIYWHHY with $K_{M}$ values of 55 and $20 \mu \mathrm{M}$, respectively [35,34]. Besides Src, other tyrosine kinases have been analyzed by combinatorial libraries, for example, Abl's specificity was analyzed by means of a one-bead one-peptide library where 14 unique Abl substrates were identified and grouped into three substrate motifs [47].

Methods other than synthetic combinatorial peptide libraries have been used to screen for kinase substrates. Phage peptide expression libraries have emerged as a method to determine peptide substrate motifs, and this approach has been applied to the Src-family protein kinases Blk, Lyn, Fyn, and Src [55]. In one study, the phage peptide library identified a novel Fyn peptide substrate EFGTYGTLS with a $K_{M}=70 \mu \mathrm{M}$ [56].

If no specific substrate is known for a kinase, a random polymer of Glu and Tyr in the ratio of 4:1 can be used for enzyme activity assays [48]. This poly $\left(\mathrm{Glu}^{4}, \mathrm{Tyr}^{1}\right)$ lacks a defined phosphorylation site or higher orders of structure and is commonly used as a generic tyrosine kinase substrate. Therefore, the activity of a kinase for this polymer is considered as general kinase activity, lacking in specificity or selectivity, and it does not add to the understanding of an enzyme's active site selectivity for specific substrates.

To date, a peptide substrate analysis of FAK via any method, combinatorial or otherwise, has not been reported. In this study, a combinatorial one-bead one-peptide library was synthesized and used to screen for FAK substrates using an on-bead kinase assay and colorimetric detection method. Edman degradation was performed on beads shown to be phosphorylated revealing 12 hit peptide sequences. These peptide substrates were resynthesized and validated by solution-phase radioisotopic labeling for kinetic evaluation. Based on results from the initial library hits, five additional peptides were designed and found to be efficiently phosphorylated by FAK. The best substrates were those determined to have negatively charged amino acids as well as bulky hydrophobic or aromatic amino acids near the tyrosine. The most active peptide substrate for FAK was DES4 (GDYVEF-KKK) with a $K_{M}=92 \mu \mathrm{M}$. This substrate may serve as a useful tool for FAK-specific activity and competition assays. Further, a consensus sequence for active FAK substrate peptides can be summarized as G/I-D-Y-V-E-F/W. Placing the peptide sequences determined in this study into activity tiers provides us a better picture of FAK substrate specificity (Table 6).

The determination of efficient substrates for FAK advances signal transduction research by providing researchers with an effective probe for monitoring the activity of this enzyme. All of the peptides analyzed here, both from the initial library screen and from the designed peptides, displayed activities higher than that reported for the generic poly [Glu, Tyr] 4:1 substrate. (The specific activity for FAK was reported as $55 \mathrm{nmol} / \mathrm{min} / \mathrm{mg}$, measured by phosphate transfer to poly [Glu, Tyr] 4:1 substrate.) Peptides in this study had $V_{\max }$ activities that ranged from 785 to $3341 \mathrm{nmol} / \mathrm{min} / \mathrm{mg}$. This increase in phosphoacceptor ability of the peptide substrates reported here likewise increases the sensitivity of FAK activity assays and may lead to enhanced screening capabilities for FAK inhibitors, as well as the design of novel non-ATP competitive inhibitors.

The identification of peptide substrates for other protein kinases has led to the development of peptide biosensors. Recent studies with peptide-based Abl and Syk biosensors have demonstrated feasibility in monitoring pharmacodynamic effects within a live cell model $[57,58]$. The translation of these efficient FAK peptide substrates into effective biosensors may shed light onto how FAK is able to sense and transduce signals within a cell, providing a tool for researchers to further address questions regarding the role of FAK in promoting tumorigenesis or metastasis.

Lastly, these substrates offer an increased understanding of the active site for this important kinase. The crystal structure of FAK has been solved with ATP bound, but little evidence has been reported on how a protein (or peptide) substrate binds in the active site [59]. The peptide substrates reported here launch

\begin{tabular}{|c|c|c|c|c|}
\hline Activity ranking & Peptide & Sequence & Efficiency $\left(V_{\max } / K_{M}\right)$ & Comments/consensus \\
\hline \multirow[t]{3}{*}{ Most active } & DES4 & GDYVEF-KKK & 20.9 & GDYVE-aromatic \\
\hline & DES3 & GDYVEW-KKK & 10.9 & IDYVE-aromatic \\
\hline & LIB6 & IDVEW-KKK & 10.5 & \\
\hline \multirow[t]{2}{*}{ Second tier } & DES1 & IDYVEF-KKK & 6.4 & IDYVE-aromatic \\
\hline & LIB12b & IDYELF-KKK & 5.0 & IDYEL-aromatic \\
\hline \multirow[t]{4}{*}{ Third tier } & DES5 & EDYELF-KKK & 1.94 & X-Y-E-I/L-aromatic/M \\
\hline & LIB12a & GDYELF-KKK & 1.46 & \\
\hline & LIB1 & NVYEIM-KKK & 1.41 & $\mathrm{X}$ varies: negative, small, hydrophobic \\
\hline & DES2 & IDYELW-KKK & 0.92 & \\
\hline \multirow[t]{9}{*}{ Other library hits } & LIB2 & GIYFHE-KKK & \multirow[t]{9}{*}{ Kinetic constants not determined } & \multirow{9}{*}{$\begin{array}{l}\text { Ranked in relative activity order from initial } \\
\text { peptide profile assay }\end{array}$} \\
\hline & LIB4 & MKYMPQ-KKK & & \\
\hline & LIB7 & INYELP-KKK & & \\
\hline & LIB8 & GIYARK-KKK & & \\
\hline & LIB5 & WNYLIH-KKK & & \\
\hline & LIB3 & GEYVVD-KKK & & \\
\hline & LIB9 & ELYQNP-KKK & & \\
\hline & LIB10 & LRYFWE-KKK & & \\
\hline & LIB11 & GKYRMV-KKK & & \\
\hline
\end{tabular}


the possibility for addressing important questions about the landscape of FAK's active site, the potential binding modes for substrates, and the development of new FAK inhibitors as novel anticancer therapeutics.

\section{Acknowledgements}

This research was supported by a professional development grant from the NSF ADVANCE PAID grant at GVSU and by the GVSU Weldon Fund. We are most grateful to the GVSU Chemistry Department faculty, staff, and students for the opportunity to pursue this research in a collegial learning environment. L. A.W. would like to thank Kevan Shokat (UCSF), Robert Smart (GVSU), Shannon Biros (GVSU), and Mary Karpen (GVSU) for support and helpful discussions through the years, Saw Kyin (Princeton University) for peptide bead sequencing and Kavita Shah (Purdue University) for an initial gift of FAK to begin the preliminary screens and controls.

\section{References}

1 Wozniak MA, Modzelewska K, Kwong L, Keely PJ. Focal adhesion regulation of cell behavior. Biochim. Biophys. Acta 2004; 1692: 103-119. DOI: 10.1016/j.bbamcr.2004.04.007.

2 Geiger B, Spatz JP, Bershadsky AD. Environmental sensing through focal adhesions. Nat. Rev. Mol. Cell Biol. 2009; 10: 21-33. DOI: 10.1038/ nrm2593.

3 Zaidel-Bar R, Itzkovitz S, Ma'ayan A, lyengar R, Geiger B. Functional atlas of the integrin adhesome. Nat. Cell Biol. 2007; 9: 858-867. DOI: 10.1038/ ncb0807-858.

4 Schaller MD, Borgman CA, Cobb BS, Vines RR, Reynolds AB, Parsons JT. Pp125FAK a structurally distinctive protein-tyrosine kinase associated with focal adhesions. Proc. Natl. Acad. Sci. U. S. A. 1992; 89: 5192-5196.

5 Comoglio PM, Boccaccio C, Trusolino L. Interactions between growth factor receptors and adhesion molecules: breaking the rules. Curr. Opin. Cell Biol. 2003; 15: 565-571. DOl: 10.1016/S0955-0674(03)00096-6.

6 Sieg DJ, Hauck CR, llic D, Klingbeil CK, Schaefer E, Damsky CH, Schlaepfer DD. FAK integrates growth-factor and integrin signals to promote cell migration. Nat. Cell Biol. 2000; 2: 249-256. DOI: 10.1038/ 35010517.

7 Schaller MD, Hildebrand JD, Shannon JD, Fox JW, Vines RR, Parsons JT. Autophosphorylation of the focal adhesion kinase, pp125fak, directs SH2-dependent binding of pp60src. Mol. Cell. Biol. 1994; 14: 1680-1688. DOI: 10.1128/MCB.14.3.1680.

8 Xing Z, Chen HC, Nowlen JK, Taylor SJ, Shalloway D, Guan JL. Direct interaction of $\mathrm{v}$-Src with the focal adhesion kinase mediated by the Src SH2 domain. Mol. Biol. Cell 1994; 5: 413-421. DOI: 10.1091/ mbc.5.4.413.

9 Schlaepfer DD, Hanks SK, Hunter T, Geer P. Integrin-mediated signal transduction linked to Ras pathway by GRB2 binding to focal adhesion kinase. Nature 1994; 372: 786-791. DOI: 10.1038/372786a0.

10 Schlaepfer DD, Jones KC, Hunter T. Multiple Grb2-mediated integrinstimulated signaling pathways to ERK2/mitogen-activated protein kinase: summation of both c-Src- and focal adhesion kinaseinitiated tyrosine phosphorylation events. Mol. Cell. Biol. 1998; 18: 2571-2585.

11 Chan PC, Lai JF, Cheng CH, Tang MJ, Chiu CC, Chen HC. Suppression of ultraviolet irradiation-induced apoptosis by overexpression of focal adhesion kinase in Madin-Darby canine kidney cells. J. Biol. Chem. 1999; 274: 26901-26906

12 Sonoda Y, Matsumoto Y, Funakoshi M, Yamamoto D, Hanks SK, Kasahara T. Anti-apoptotic role of focal adhesion kinase (FAK). Induction of inhibitor-of-apoptosis proteins and apoptosis suppression by the overexpression of FAK in a human leukemic cell line, HL-60. J. Biol. Chem. 2000; 275: 16309-16315.

13 Lim S-T, Chen XL, Lim Y, Hanson DA, Vo T-T, Howerton K, Larocque N, Fisher SJ, Schlaepfer DD, llic D. Nuclear FAK promotes cell proliferation and survival through FERM-enhanced p53 degradation. Mol. Cell 2008; 29: 9-22. DOI: 10.1016/j.molcel.2007.11.031.

14 Tremblay L, Hauck W, Aprikian AG, Begin LR, Chapdelaine A, Chevalier S. Focal adhesion kinase (pp125FAK) expression, activation and association with paxillin and p50CSK in human metastatic prostate carcinoma. Int. J. Cancer 1996; 68: 164-171.

15 Harte MT, Hildebrand JD, Burnham MR, Bouton AH, Parsons JT. P130Cas, a substrate associated with $\mathrm{v}$-Src and $\mathrm{v}$-Crk, localizes to focal adhesions and binds to focal adhesion kinase. J. Biol. Chem. 1996; 271: 13649-13655.

16 Shen Y, Schaller MD. Focal adhesion targeting: the critical determinant of FAK regulation and substrate phosphorylation. Mol. Biol. Cell 1999; 10: 2507-2518.

17 Tachibana K, Urano T, Fujita H, Ohashi Y, Kamiguchi K, Iwata S, Hirai H, Morimoto C. Tyrosine phosphorylation of Crk-associated substrates by focal adhesion kinase: a putative mechanism for the integrin-mediated tyrosine phosphorylation of Crk-associated substrates. J. Biol. Chem. 1997; 272: 29083-29090. DOI: 10.1074/jbc.272.46.29083.

18 Han DC, Shen T-L, Guan J-L. Role of Grb7 targeting to focal contacts and its phosphorylation by focal adhesion kinase in regulation of cell migration. J. Biol. Chem. 2000; 275: 28911-28917. DOI: 10.1074/jbc. M001997200.

19 Golubovskaya VM, Kweh FA, Cance WG. Focal adhesion kinase and cancer. Histol. Histopathol. 2009; 24: 503-510.

20 Akasaka T, van Leeuwen RL, Yoshinaga IG, Mihm MC, Jr, Byers HR. Focal adhesion kinase ( $p 125 F A K$ ) expression correlates with motility of human melanoma cell lines. J. Invest. Dermatol. 1995; 105: 104-108.

21 Cance WG, Harris JE, lacocca MV, Roche E, Yang X, Chang J, Simkins S, $\mathrm{XU}$ L. Immunohistochemical analyses of focal adhesion kinase expression in benign and malignant human breast and colon tissues: correlation with preinvasive and invasive phenotypes. Clin. Cancer Res. 2000; 6: 2417-2423.

22 McCormack SJ, Brazinski SE, Moore JL, Jr, Werness BA, Goldstein DJ. Activation of the focal adhesion kinase signal transduction pathway in cervical carcinoma cell lines and human genital epithelial cells immortalized with human papillomavirus type 18. Oncogene 1997; 15: 265-274. DOI: 10.1038/sj.onc.1201186.

23 McLean GW, Avizienyte E, Frame MC. Focal adhesion kinase as a potential target in oncology. Expert Opin. Pharmacother. 2003; 4: 227-234. DOI: 10.1517/14656566.4.2.227.

24 Zhao J, Guan J-L. Signal transduction by focal adhesion kinase in cancer. Cancer Metastasis Rev. 2009; 28: 35-49. DOI: 10.1007/s10555-008-9165-4.

25 Judson PL, He X, Cance WG, Van Le L. Overexpression of focal adhesion kinase, a protein tyrosine kinase, in ovarian carcinoma. Cancer 1999; 86: 1551-1556.

26 Recher C, Ysebaert L, Beyne-Rauzy O, Mas VM-D, Ruidavets J-B, Cariven P, Demur C, Payrastre B, Laurent G, Racaud-Sultan C. Expression of focal adhesion kinase in acute myeloid leukemia is associated with enhanced blast migration, increased cellularity, and poor prognosis. Cancer Res. 2004; 64: 3191-3197. DOI: 10.1158/0008-5472.CAN-03-3005.

27 Sulzmaier FJ, Jean C, Schlaepfer DD. FAK in cancer: mechanistic findings and clinical applications. Nat. Rev. Cancer 2014; 14: 598-610. DOI: $10.1038 /$ nrc3792.

28 Jean C, Chen XL, Nam J-O, Tancioni I, Uryu S, Lawson C, Ward KK, Walsh $C T$, Miller NLG, Ghassemian M, Turowski $P$, Dejana $E$, Weis $S$, Cheresh DA, Schlaepfer DD. Inhibition of endothelial FAK activity prevents tumor metastasis by enhancing barrier function. J. Cell Biol. 2014; 204: 247-263. DOI: 10.1083/jcb.201307067.

29 Hochwald SN, Nyberg C, Zheng M, Zheng D, Wood C, Massoll NA, Magis A, Ostrov D, Cance WG, Golubovskaya VM. A novel small molecule inhibitor of FAK decreases growth of human pancreatic cancer. Cell Cy. (Georgetown, Tex.) 2009; 8: 2435-2443.

30 Golubovskaya VM, Figel S, Ho BT, Johnson CP, Yemma M, Huang G, Zheng $M$, Nyberg C, Magis A, Ostrov DA, Gelman IH, Cance WG. A small molecule focal adhesion kinase (FAK) inhibitor, targeting Y397 site: 1-(2-hydroxyethyl)-3, 5, 7-triaza-1-azoniatricyclo [3.3. 1.13, 7] decane; bromide effectively inhibits FAK autophosphorylation activity and decreases cancer cell viability, clonogenicity and tumor growth in vivo. Carcinogenesis 2012; 33: 1004-1013. DOI: 10.1093/ carcin/bgs 120 .

31 Golubovskaya V, Beviglia L, Xu L-H, Earp HS, Craven R, Cance W. Dual inhibition of focal adhesion kinase and epidermal growth factor receptor pathways cooperatively induces death receptor-mediated apoptosis in human breast cancer cells. J. Biol. Chem. 2002; 277: 38978-38987. DOI: 10.1074/jbc.M205002200.

32 Infante JR, Camidge DR, Mileshkin LR, Chen EX, Hicks RJ, Rischin D, Fingert $\mathrm{H}$, Pierce $\mathrm{K}, \mathrm{Xu} \mathrm{H}$, Roberts WG, Shreeve SM, Burris HA, Siu LL. Safety, pharmacokinetic, and pharmacodynamic phase I doseescalation trial of PF-00562271, an inhibitor of focal adhesion kinase, in 
advanced solid tumors. J. Clin. Oncol. 2012; 30: 1527-1533. DOI: 10.1200/ JCO.2011.38.9346.

33 Falciani C, Lozzi L, Pini A, Bracci L. Bioactive peptides from libraries. Chem. Biol. 2005; 12: 417-426. DOI: 10.1016/j.chembiol.2005.02.009.

34 Lou Q, Leftwich ME, Lam KS. Identification of GIYWHHY as a novel peptide substrate for human $\mathrm{p} 60^{\mathrm{c}-\mathrm{src}}$ protein tyrosine kinase. Bioorg. Med. Chem. 1996; 4: 677-682. DOI: 10.1016/0968-0896(96)00063-6.

35 Lam KS, Wu J, Lou Q. Identification and characterization of a novel synthetic peptide substrate specific for Src-family protein tyrosine kinases. Int. J. Pept. Protein Res. 1995; 45: 587-592. DOl: 10.1111/j.13993011.1995.tb01323.x.

36 Kim Y-G, Shin D-S, Kim E-M, Park H-Y, Lee C-S, Kim J-H, Lee B-S, Lee Y-S, Kim B-G. High-throughput identification of substrate specificity for protein kinase by using an improved one-bead-one-compound library approach. Angew. Chem. 2007; 119: 5504-5507. DOI: 10.1002/ ange. 200700195.

37 Lam KS, Salmon SE, Hersh EM, Hruby VJ, Kazmierski WM, Knapp RJ. A new type of synthetic peptide library for identifying ligand-binding activity. Nature 1991; 354: 82-84. DOI: 10.1038/354082a0.

38 Lam KS, Lebl M, Krchňák V. The "one-bead-one-compound" combinatorial library method. Chem. Rev. 1997; 97: 411-448. DOI: $10.1021 /$ cr9600114.

39 McBride JD, Freeman HN, Leatherbarrow RJ. Identification of chymotrypsin inhibitors from a second-generation template assisted combinatorial peptide library. J. Pept. Sci. 2000; 6: 446-452. DOI: 10.1002/1099-1387(200009)6:9<446::aid-psc283>3.0.co;2-u.

40 Marani MM, Oliveira E, Côte S, Camperi SA, Albericio F, Cascone O. Identification of protein-binding peptides by direct matrix-assisted laser desorption ionization time-of-flight mass spectrometry analysis of peptide beads selected from the screening of one bead-one peptide combinatorial libraries. Anal. Biochem. 2007; 370: 215-222. DOI: 10.1016/j.ab.2007.07.032.

41 Beebe KD, Wang P, Arabaci G, Pei D. Determination of the binding specificity of the SH2 domains of protein tyrosine phosphatase SHP-1 through the screening of a combinatorial phosphotyrosyl peptide library. Biochemistry 2000; 39: 13251-13260.

42 Wavreille A-S, Garaud M, Zhang Y, Pei D. Defining SH2 domain and PTP specificity by screening combinatorial peptide libraries. Methods 2007; 42: 207-219. DOI: 10.1016/j.ymeth.2007.02.010.

43 Songyang Z, Carraway KL, III, Eck MJ, Harrison SC, Feldman RA, Mohammadi M, Schlessinger J, Hubbard SR, Smith DP, Eng C, Lorenzo MJ, Poner BAJ, Mayer BJ, Cantley LC. Catalytic specificity of protein-tyrosine kinases is critical for selective signalling. Nature 1995; 373: 536-539.

44 Lam KS, Liu R, Miyamoto S, Lehman AL, Tuscano JM. Applications of onebead one-compound combinatorial libraries and chemical microarrays in signal transduction research. Acc. Chem. Res. 2003; 36: 370-377. DOI: 10.1021/ar0201299.

45 Kim M, Shin DS, Kim J, Lee YS. Substrate screening of protein kinases: detection methods and combinatorial peptide libraries. Biopolymers 2010; 94: 753-762. DOI: 10.1002/bip.21506.

46 Martin SE, Peterson BR. A colorimetric enzyme-linked on-bead assay for identification of synthetic substrates of protein tyrosine kinases. J. Pept. Sci. 2002; 8: 227-233. DOI: 10.1002/psc.376.
$47 \mathrm{Wu} \mathrm{JJ}$, Afar DE, Phan H, Witte ON, Lam KS. Recognition of multiple substrate motifs by the C-ABL protein tyrosine kinase. Comb. Chem. High Throughput Screen. 2002; 5: 83-91.

48 Braun S, Raymond WE, Racker E. Synthetic tyrosine polymers as substrates and inhibitors of tyrosine-specific protein kinases. J. Biol. Chem. 1984; 259: 2051-2054.

49 Songyang Z, Carraway KL, Eck MJ, Harrison SC, Feldman RA, Mohammadi M, Schlessinger J, Hubbard SR, Smith DP, Eng C, Lorenzo MJ, Ponder BAJ, Mayer BJ, Cantley LC. Catalytic specificity of protein-tyrosine kinases is critical for selective signalling. Nature 1995; 373: 536-539.

50 Songyang Z, Cantley LC. Recognition and specificity in protein tyrosine kinase-mediated signalling. Trends Biochem. Sci. 1995; 20: 470-475. DOI: 10.1016/S0968-0004(00)89103-3.

51 Swarup G, Dasgupta JD, Garbers DL. Tyrosine protein kinase activity of rat spleen and other tissues. J. Biol. Chem. 1983; 258: 10341-10347.

52 Hastie CJ, McLauchlan HJ, Cohen P. Assay of protein kinases using radiolabeled ATP: a protocol. Nat. Protocols 2006; 1: 968-971.

53 Casnellie JE, Harrison ML, Pike L, Hellström KE, Krebs EG. Phosphorylation of synthetic peptides by a tyrosine protein kinase from the particulate fraction of a lymphoma cell line. Proc. Natl. Acad. Sci. U. S. A. 1982; 79: 282-286.

54 Houseman BT, Huh JH, Kron SJ, Mrksich M. Peptide chips for the quantitative evaluation of protein kinase activity. Nat. Biotechnol. 2002; 20: 270-274. DOI: 10.1038/nbt0302-270.

55 Schmitz R, Baumann G, Gram H. Catalytic specificity of phosphotyrosine kinases Blk, Lyn, c-Src and Syk as assessed by phage display. J. Mol. Biol. 1996; 260: 664-677. DOI: 10.1006/jmbi.1996.0429.

56 Dente L, Vetriani C, Zucconi A, Pelicci G, Lanfrancone L, Pelicci PG, Cesareni G. Modified phage peptide libraries as a tool to study specificity of phosphorylation and recognition of tyrosine containing peptides. J. Mol. Biol. 1997; 269: 694-703. DOI: 10.1006/jmbi.1997.1073.

57 Lipchik AM, Killins RL, Geahlen RL, Parker LL. A peptide-based biosensor assay to detect intracellular syk kinase activation and inhibition. Biochemistry 2012; 51: 7515-7524. DOl: 10.1021/bi300970h.

58 Placzek EA, Plebanek MP, Lipchik AM, Kidd SR, Parker LL. A peptide biosensor for detecting intracellular Abl kinase activity using matrix-assisted laser desorption/ionization time-of-flight mass spectrometry. Anal. Biochem. 2010; 397: 73-78. DOI: 10.1016/j.ab.2009.09.048.

59 Nowakowski J, Cronin CN, McRee DE, Knuth MW, Nelson CG, Pavletich NP, Rogers J, Sang B-C, Scheibe DN, Swanson RV, Thompson DA. Structures of the cancer-related Aurora-A, FAK, and EphA2 protein kinases from nanovolume crystallography. Structure 2002; 10: 1659-1667. DOI: 10.1016/S0969-2126(02)00907-3.

\section{Supporting Information}

Additional supporting information may be found in the online version of this article at the publisher's website. 